\title{
Use of Citation Data for Periodicals Control in Libraries: A Response to Broadus
}

\author{
Maurice B. Line
}

The rank order of periodicals requested from the British Library Lending Division shows a low stability over time. These findings suggest that the citation-count approach recommended by Broadus should be used with considerable caution.

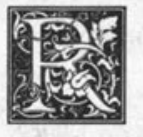

obert Broadus' paper on the use of Journal Citation Reports (JCR) for reducing periodical subscriptions is interesting, but like other papers on this topic it misses a crucial practical issue. Stephen Bensman's paper is equally interesting; some of the comments below apply to it also.

Librarians want to know (1) what periodicals to cancel if they are short of funds and (2) what additional titles to buy. For both purposes, apart from new titles in the case of (2), they are concerned with titles at the fringe of use. While citation rank lists may not correlate badly with local use of all periodicals held, the correlation grows weaker as one goes further down the lists. This is inevitable if only because the number of citations or uses at the fringes is small or very small. It is a matter of chance whether a little-used or little-cited title receives, in any one year, zero, one, two, three, four, or five uses or citations, although the rank order may be dramatically affected.

Broadus admits that $J C R$ are only a rough guide for identifying low-use periodicals. I doubt if it is of much use even as a rough guide. Not only may little-cited periodicals be retained for various rea- sons, as he says-among them special local interest; but some highly cited periodicals, which would not be picked out by his procedure, may easily be very little used in a local library, because they are marginal to its interests. One library's (or database's) core is another's fringe.

The rank order of periodicals requested from the British Library Lending Division shows a low stability over time. ${ }^{1,2}$ There was between 1975 and 1980 only 55 percent overlap in the top one thousand titles, and between 1980 and 1983 (a shorter period) only 60 percent. It would be interesting to study the stability of rank lists of periodicals in order of use in a few academic or special libraries; my guess is that stability would be little if any better than at the British Library Lending Division, since the clientele changes, and subject interests and emphases of existing users change (my personal rank list of periodicals in order of use changes from year to year). Over large numbers of users, individual changes might perhaps be expected to be submerged in an overall consistency, but the Lending Division evidence suggests that this does not happen.

If there is instability of use over quite

Maurice B. Line is director general of the British Library Lending Division, Boston Spa, Wetherby, West Yorkshire LS23 7BQ, United Kingdom. 
short periods in any ordinary academic library, the pursuit of precise optimization may be like the hunting of the snark, for the 'optimal' collection will vary from year to year. In this case, librarians may as well rely on what their users say they want in the first place. Users may be wrong, but at least they will be happy, and if they are so wrong that they become unhappy, it will be their own fault.

The trouble with this is that new periodicals can usually be bought only at the expense of existing ones, and while users say what they do want, they don't normally say what they don't want. The problem is thus one of keeping up with changing or declining local interests, and possibly with declining periodicals. JCR might conceivably help to identify some of the latter, but certainly not the former.

There seem to be two alternatives. The first is some regular form of monitoring the use of fringe periodicals. This is tedious, it is possibly expensive, and it demands users' cooperation. It is difficult to make data collection reliable, and because of random fluctuations in use, decisions need to be made on the basis of at least three years' data. When data on use have been gathered, costs also need to be taken into account-a periodical costing $£ 20$ and receiving five uses is a better value than one costing $£ 100$ and receiving ten. The other alternative is informed guessworkinformed by the observations of library staff and by the comments of users. The first method, if properly conducted, is more accurate but not necessarily more cost effective.

The stability of $J C R$ rank order is much greater than that of the Lending Division rank order. ${ }^{3}$ (The overlap between lists in $J C R$ three years apart is about 90 percent). There are good reasons for this; one of the reasons and one of the conclusions is that citations reflect actual use imperfectly and so cannot be used with much confidence by librarians.

If it is worth pursuing the use of $J C R$ at all, we do not need more studies of general correlations between JCR rank lists and library uses, but studies of correlations at the fringes of use. Without such studies a fruitless discussion could go on foreverproducing articles but little else.

\section{REFERENCES}

1. Ann Clarke, "The Use of Serials at the British Library Lending Division," Interlending Review 9:111-17 (Oct. 1981).

2. Karen Merry and Trevor Palmer, "Use of Serials at the British Library Lending Division in 1983," Interlending and Document Supply 12:56-60 (Apr. 1984).

3. Maurice B. Line, "Changes in Rank Lists of Serials over Time: Interlending vs Citation Data," Interlending and Document Supply 12 (Oct. 1984). This short article also appears in the "Research Notes"' section of this issue of CERL, p.77-79. 